\title{
Suluca (Lapseki-Çanakkale) Katenasında Toprak Özellikleri ve Taksonomik Değişim
}

\author{
Gamze Sivrikaya* iD Hüseyin Ekinci $^{*}$ \\ ${ }^{1}$ Çanakkale Onsekiz Mart Üniversitesi, Ziraat Fakültesi, Toprak Bilimi ve Bitki Besleme Bölümü, Çanakkale \\ *Sorumlu yazar: gamze_svrky@hotmail.com
}

Geliş Tarihi: 26.02.2021

Kabul Tarihi: 22.05.2021

\section{$\ddot{\mathbf{O} z}$}

$\mathrm{Bu}$ çalışmada Suluca-Kocaveliköy (Lapseki-Çanakkale) katenasında beş adet toprak profili incelenmiştir. Farklı rakım ve topoğafyada yer alan toprak profillerinin morfolojik tanımlaması yapılarak, her bir horizondan toprak örnekleri alınmıştır. Çalışma, toprak örneklerinde fiziksel, kimyasal ve bazı minerolojik (XRD, SEM, oksit) analizler yapılarak önemli özelliklerinin saptanması, katenasal farklılıkların toprak oluşu ve sınıflandırılmasına etkisinin ortaya konulması amacıyla yapılmıştır. Laboratuvar analizi sonuçlarına göre toprak profillerinde genel olarak kumlu kil ve kil tekstür sınıfının baskın olduğu görülmüştür. Toprak asitliği $(\mathrm{pH})$ genellikle hafif alkalin olarak bulunmuştur. Organik madde içeriğinin \% $0,13-15,9$ arasında olduğu belirlenmiştir. Katyon değişim kapasitesi (KDK) değerleri 12,60-43 $\mathrm{cmol} \mathrm{kg}^{-1}$ arasında bulunmuştur. Toprak profillerinde toprak oluşumunun incelenmesinde $\mathrm{SiO}_{2} / \mathrm{Al}_{2} \mathrm{O}_{3}$ gibi ayrışma oranları ve kimyasal alterasyon indeksi (CIA) gibi indeksler kullanılmıştır. Bu indekslere göre, en yüksek kimyasal ayrışma değeri 83 olarak bulunmuştur. İcelenen profiller, analiz sonuçlarına ve morfolojik gözlemlere bağlı olarak toprak taksonomisi ve WRB sınıflandırma sistemine göre sınıflandırılmıştır. Toprak proilleri toprak taksonomisine göre entisol, inceptisol, mollisol ve vertisol ordolarında, WRB sistemine göre ise calcisols, phaozems, leptosols, vertisols ve cambisols referans toprak gruplarında sınıflandırılmıştır.

Anahtar kelimeler: Toprak Profili, Suluca, Toprak Taksonomisi, Katena

\section{Taxonomic Changes and Soil Properties in Suluca-Kocaveli Soil Catena (Lapseki- Çanakkale)}

\section{Abstract}

In this study, five soil profiles were investigated in Suluca-Kocaveliköy (Lapseki-Çanakkale). Soil samples were taken from each horizon by making the morphological description of soil profiles in different altitudes and topography. In this study, physical, chemical and some mineralogical (XRD, SEM, oxide) analyzes were performed to determine the important properties of soils and to determine the effect of catena differences on the formation and classification of soils. According to the results of the laboratory analysis, sandy clay and clay texture class was dominant in the soil profiles. The soil acidity $(\mathrm{pH})$ was generally found to be slightly alkaline. Organic matter were between $0,13-15.9 \%$ and the cation exchange capacity (CEC) values were between $12.60-43 \mathrm{cmol} \mathrm{kg}^{-1}$. Weathering rates such as $\mathrm{SiO}_{2} / \mathrm{Al}_{2} \mathrm{O}_{3}$ and chemical alteration index (CIA) were used in the soil profiles. According to these indexes, the highest chemical weathering value was found to be 83 . The examined profiles were classified according to the soil taxonomy and WRB classification system depending on the analyses results and the morphological observations. Soil profiles were classifed as an entisols, inceptisols, mollisols and vertisols orders and as calcisols, phaozems, leptosols, vertisols and cambisols reference soil groups according to the soil taxonomy and WRB system, respectively.

Keywords; Soil Profile, Suluca, Soil Taxonomy, Catena

\section{Giriş}

Katena, Toprak Bilimi Terimler Sözlüğünde benzer ana materyal ve benzer iklim koşulları altında ortaya çıkan fakat rölief ve drenajdaki farklılık nedeniyle farklı karakteristiklere sahip yaklaşık aynı yaştaki toprak dizisi olarak tanımlanmaktadır (Anonim, 1996). Kiyuchevskii (1972)'e göre.bu kavram, çeşitli yazarlar tarafından düzenlenmiş olmakla birlikte, özellikle Busenell $(1942,1944,1958)$ tarafından ele alınmış ve günümüzde A.B.D. de "toposequens" terimi yerine kullanılmaya 
başlanmıştır. Toposequens terimi, morfolojik bir ayrımdır ve rengin (özellikle gri ton) yükseklik ve hidrolojiyle değişimini kapsamaktadır. Katena ise anlam olarak bir toprak oluşum olayı ve bunun sonuçlarını yansıtmaktadır.

Bazı araziler belli bir kullanım türünün gereksinimlerini çok az karşılarken diğer bir kullanım türünün tamamını karşılayabilir. Değişik özelliklerdeki toprakların üretken olarak kullanılması için çeşitli kullanım türleri göz önüne alınarak bir planlamaya gidilmesi şarttır (FAO, 1976; Dent ve Young, 1981). Bu nedenle, karmaşık bir yapıya sahip olan toprakların diğer tüm varlıklarda olduğu gibi sınıflandırılmaları gerekmektedir. Toprakların sınıflandırılması ise toprak profillerinin ayrıntılı incelenmesi ve her bir toprak horizonunun oluşumunun saptanması ile mümkündür. Bunun için incelenen toprak profilinin, her bir horizonundan alınan toprak örneklerinin morfolojik, fiziksel, kimyasal ve mineralojik özelliklerinin belirlenmesi gerekmektedir.

Applegarth ve Dahms (2001), USA, Wyoming, Whiskey havzasının kireç morenleri katenalarının toprağını araştırmışlardır. Araştırmacılar, iki farklı moren alanının her birine ait devrin (çağın) katenasını incelemişlerdir. Bunlar The Jakey's Fork ve Torrey Creek vadileridir. Jakey's Fork'daki Bull gölü katenasının topraklarının aynı alanın pinedale katenasındakinden daha gelişmiş olduğu belirlenmiştir. Bunlar yaşların daha büyük olmasından dolayı daha kalın soluma, daha fazla horizona, daha fazla pedogenetik kile ve daha fazla pedogenetik karbonata sahiptirler. Katena gelişimindeki farklılıkların çoğunlukla Jakey's Fork ve Torrey Creek katenası arasındaki eğim uzunluğundaki farklılıklardan etkilendiği belirlenmiştir. Katena gelişiminde topoğrafik konumun rolünün Jakey's Fork katenalarında Torrey Creek katenalarındakinden daha az olduğu saptanmıştır.

Başarlar ve Ekinci (2019), Bayramiç-Çan arasında kalan farklı jeolojik- jeomorfolojik yapıya sahip yaklaşı $50 \mathrm{~km}$ 'lik alanda yürüttükleri çalışmada, yedi adet toprak profilinin morfolojik tanımlanmasını yaparak toprakların fizikokimyasal ve bazı mineralojik özelliklerini incelemişlerdir. Araştırıcılar çalışma sonucunda, en yüksek kil içeriği (\% 47,75) ve en yüksek KDK (47 cmol kg -1) miktarı ile eski göl terasında oluşmuş vertisol profilinde saptamışlardır. Bunun yanında araştırma alanı toprakları Toprak taksonomisinin alfisol, mollisol, inceptisol, entisol ve vertisol ordolarında, WRB siniflandirma sisteminde ise phaozems, luvisols, calcisols, cambisols, fluvisols ve vertisols referans gruplarında sınıflandırılmıştır.

Timpson ve ark. (1982), Girit adasının kuzeydoğu kesimindeki Kuvaterner yaşlı alüvyon üzerinde oluşan bir toposekuens boyunca toprakların mineralojik bileşimini incelemişlerdir. Çalışmada toposequens boyunca 3 farklı arazi şekli belirlenmiş bunlar üzerinde dört toprak tanımlanmıştır. Fluventinc ve Calcixerollic Xerochrepts olarak sınıflandırılmış olan topraklarda eğim \%2-5 arasında olup derinlikle birlikte azalan kil ve organik madde içeriğine bağlı olarak KDK miktarı da azalmıştır. Toprak profillerinin herbir horizonunun silt ve kil fraksiyonlarındaki mineralojik analizlerde $\mathrm{x}$-ray difraksiyonu ve elektron mikroskop teknikleri kullanılmıştır. Toprakların kaba ve ince silt fraksiyonlarında dolomit, kalsit, kuvars, feldspat, mika ve klorit içerdiği, feldspatların derinlikle birlikte azaldığı ve kalsitin ise arttığı saptanmıştır. Kil fraksiyonunda ise dominant olarak trioktahedral demir klorit ve mika (muskovit) belirlenmiştir.

Weitkamp ve ark., (1996) mevsimsel yaş arazilerin Entisol- Alfisol- Vertisol katenası üzerinde yaptıkları çalışmada toprak morfolojisi, toprağın kimyasal özellikleri ve topraktaki su hareketi arasındaki ilişkiyi incelemiştir. Yapılan çalışmada doruk ve etek kısmında sığ ve kaba-tınlı Entisoller, etek düzlügünde (footslope) prizmatik strüktürlü killi Alfisoller saptanmıştır. Taban ve etek ucu düzlüğünde (toeslope) kuvvetli köşeli blok strüktüre ve kayma yüzeylerine (slickenside) sahip Vertisol topraklarını saptamışlardır.

Yüksel ve Ekinci (2019), Meriç havzasında inceledikleri yaşlı alüviyal teras üzerinde oluşmuş bir toprak profilinde $\mathrm{SiO}_{2} / \mathrm{Al}_{2} \mathrm{O}_{3}$ oranının alt katmanlara doğru azaldığını, bu durumun profilde bir kil illuviasyonunun varlığına işaret ettiğini belirtmişlerdir.

Tegene (1997), Etiyopya'da, Welo, yukarı Watiya havzasında birbirine benzer ve birbirine zit tepe eğimlerinde toprak katenasının özelliklerini incelemiştir. Toprak üniteleri FAO/UNESCO Dünya Toprak Haritasının gözden geçirilmiş lejandına göre saptanmıştır. Her iki tepe eğim tiplerinin zirve ve arka eğimi fazlaca aşınmaya uğramıştır. Leptosoller için sınıflama gereksinimlerini karşılayan sığ topraklar olarak belirlenmiştir. $\mathrm{Ap} / \mathrm{Bw} / \mathrm{Cr}$ horizon dizilimiyle benzer yamaç eğimleri üstündeki pedon oldukça aşınmış olması nedeniyle bozunmuş Haplic Phaeozem olarak sınıflandırılmıştır. Tipik $\mathrm{A} / \mathrm{CB} / \mathrm{Bb}$ horizon düzenine sahip benzer topuk eğimi üzerindeki topraklar ise Eutric regosoller olarak 
sınılanddırılmıştır.. Günümüz veya Üst Halosen'den önce 4000 yıldan birkaç yüzyıl arasında değişen yaş diliminde görülen topuk eğim üzerindeki modern ve gömülü toprakların dizilimi toprak stratigrafisi olarak kolon şeklinde gözlemlenmiştir. Stratigrafik kolonun temelinde Eutric Vertisol olarak tanımlanan en yaşlı gömülü toprak birbirine zıt tepe eğimlerinin birbirine yakın topuk eğimleri üzerindeki yüzeylerde ortaya çıktı̆̆ 1 belirlenmiştir. Birbirine zıt tepe eğiminin yamaç eğimle bitiştiği yerleri kaplayarak üst eğimlerde de yayılım gösteren gömülü olmayan Vertisollerin, koyu kahverengiden çok koyu gri renklere kadar kalın dikey profile ve $\mathrm{A} / \mathrm{AC}$ veya $\mathrm{A} / \mathrm{C} / \mathrm{Cr}$ horizon dizilimine sahip olduğu görülmüştür.

Toprak-Su Genel Müdürlüğü (Mülga) tarafından Türkiye çapında başlatılan (1966-1971) havza bazlı çalışma sonucunda, 1938 eski Amerikan sisteminin büyük grupları ve bunların önemli fazlarının haritalama ünitesi olarak kullanıldığı 1:200.000 ölçekli toprak harita ve raporları hazırlanmıştır. Bu çalışmalar sonraki yıllarda revize edilmiştir. İl bazında 1:100.000 ölçekli olarak hazırlanan bu haritalara göre çalışma alanında kolüviyal ve kahverengi orman toprakları yer almaktadır (Anonim, 1999). Söz konusu büyük grupları içeren Suluca-Kocaveliköy (LapsekiÇanakkale) katenasında yürütülen bu araştırmada, benzer ana materyal ve benzer iklim koşulları altında oluşmuş, ancak topoğrafya ve drenaj gibi faktörlerin farklılığı nedeniyle profil gelişimi, morfolojik, fiziksel, kimyasal ve mineralojik özellikleri farklı olan topraklar incelenmiştir. Araştırılan topraklar, taksonomik değişimi görmek amaciyla Toprak Taksonomisi (Soil Survey Staff, 2014) ve IUSS- WRB (2015) toprak sınıflandırma sistemlerine göre sınıflandırılmıştır.

\section{Materyal ve Yöntem}

\section{Çalışma alanı ve coğrafi konumu}

Suluca -Kocaveliköy katenası Çanakkale ili Lapseki ilçesi sınırları içerisinde yer almaktadır. Çalışmada, belirlenen alanda farklı topoğrafik konumlarda toplam 5 adet toprak profili açılmış ve her bir profilin farklı derinliklerindeki tüm katmanlarından toplam 29 adet toprak örneği alınmıştır (Şekil 1). Bunun yanında yöreye ait eski toprak haritaları, jeoloji haritaları, topoğrafik haritalar ve uydu görüntüleri kartografik materyal olarak kullanılmıştır.

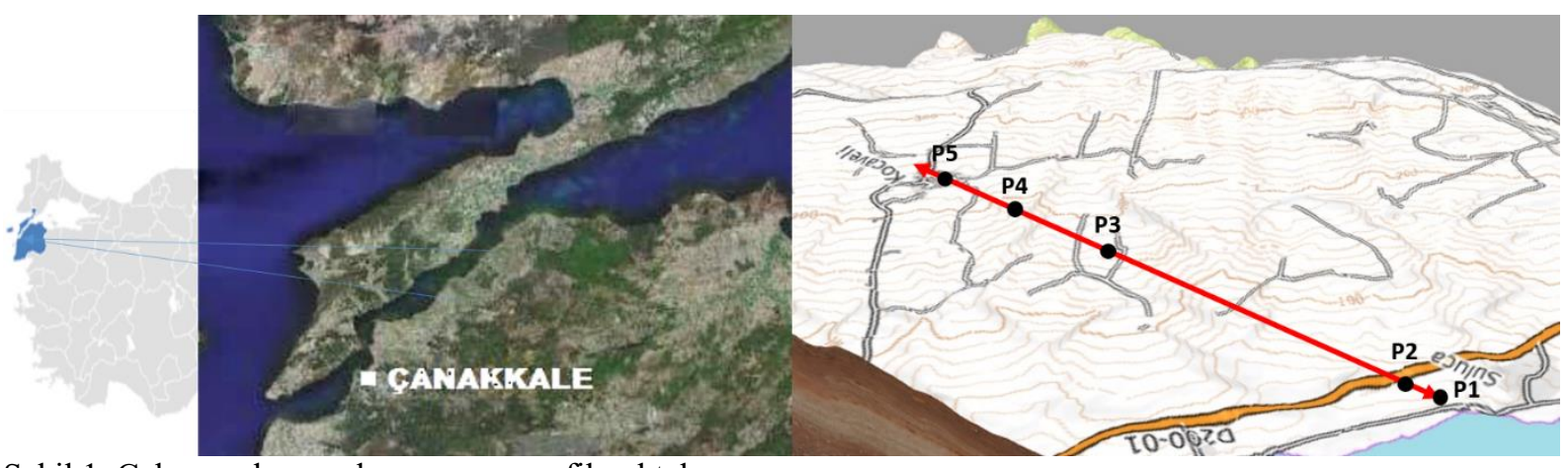

Şekil 1. Çalışma alanının konumu ve profil noktaları

\section{İklimi ve özellikleri ve Doğal bitki örtüsü}

Çalışma alanında çeşitli iklim özelliklerine sahip Marmara Bölgesi iklim özelliği hakimdir. Yörenin yıllık ortalama sıcaklığ $15,1{ }^{\circ} \mathrm{C}$ dir. Kış ayları sıcaklık ortalamas $1.0{ }^{\circ} \mathrm{C}$, yaz ayları sıcaklık ortalaması ise $22{ }^{\circ} \mathrm{C}$ 'dir. En soğuk ay $6,2{ }^{\circ} \mathrm{C}$ ile ocak ay1 ve en sicak ay $24,9{ }^{\circ} \mathrm{C}$ ile ağustos ayıdır. Bölgede yıllık ortalama yağış $616,2 \mathrm{~mm}$ 'dir. Kurak dönemdeki ortalama aylık yağış miktarı 10,97 mm iken, kış aylarındaki miktar ise 89 mm'dir. Yıllık toplam yă̆ışın \%43'ü kış aylarında, \%28'i sonbaharda, \%22'si ilkbaharda ve \%7'si de yaz aylarında düşmektedir (DMİ, 2016). Yörede toprak nem rejimi xeric, toprak sicaklık rejimi ise thermic olarak belirlenmiştir.

Lapseki ilçesi Akdeniz ve Karadeniz vejetasyon sahaları arasında bir geçiş yeri özelliği taşımaktadır. Ancak, araştırma sahasının meteorolojik verilerine göre bu alanda Akdeniz ikliminin daha baskın olduğu görülmektedir. Kıyı kesimlerinde bazı maki türleriyle kızılçamın hâkim türleri oluşturması bunu desteklemektedir (Güngördü, 1993). Çalışılan arazi, doğal bitki örtüsü olarak meşe ağırlıklı fundalık ve karaçalıdan oluşmaktadır. Kültür bitkisi olarak özellikle şeftali, kiraz, elma ve erik gibi meyveler ile domates ve biber gibi sebzeler yer almaktadır. 


\section{Jeoloji ve jeomorfoloji}

Lapseki'nin jeolojik yapısına yönelik yapılan bir çalışmada yörenin İntepe formasyonuna dahil olduğu belirtilmektedir. Bu formasyon; çakı1lı konglomera, kalkarenit, silt taşı, kumtaşı ve çamur taşlarından oluşmaktadır. Çamur taşları gri-yeşil renklidir ve bol miktarda fosil veya kırık kabuk içermektedir. Ek olarak, karbonlu bitki kök izleri ve kaliş nodülleri de çamur taşlarında görülür. Çamur taşları genellikle merceksi tabakalara sahip birkaç $\mathrm{cm}-\mathrm{mm}$ kalınlığında kumtaşları içerir. Kumtaşları düzlemsel paralel ve ripil çapraz tabakalar olarak gözlemlenmektedir. Kumtaşları, flaser ve dalgalı çamur taşları ile bir arada yer almaktadır. Çok parçalanmış kırmataşlı kumtaşları ve çakıl konglomeralar, çamur taşları ve aşınmış alt yüzeye sahip kumtaşları ile düzlemsel kavisli katmanlar şeklinde çökelleri oluşturmaktadır. Genel olarak, fosiller, kavkı parçaları ve ince tabakalı kalkarenitler bakımından zengindir (Atabey ve ark., 2004).

Suluca'dan Kocaveli'ye doğru Alçıtepe üyesine ait kalkarinit, kireç taşı (gel-git karbonat vb) kum taşı, marn gibi birimler göze çarpmaktadır. Suluca civarında jeolojik yapıyı Çamrak dere üyesine ait kumtaşı, kalkarinit, marn, kiltaşı vb (lagün gel-git düzlüğü) birimler oluşturmaktadır (MTA, 2008). Çalışma alanında jeomorfolojik yapı, Suluca civarında kolüviyal etek düzü arazileri, daha sonra sırasıyla yamaç araziler, sırt ve tepe üstü düzlüklerinden oluşmaktadır (Şekil 2).

Suluca- Kocaveli köyleri arasında yer alan katenada kolüviyal ve kahverengi orman büyük grup toprakları yer almaktadır. Çalışma alanında açılan 5 adet toprak profilinin topoğrafik konumu ve profil görünümleri Şekil 2'de sunulmuştur.

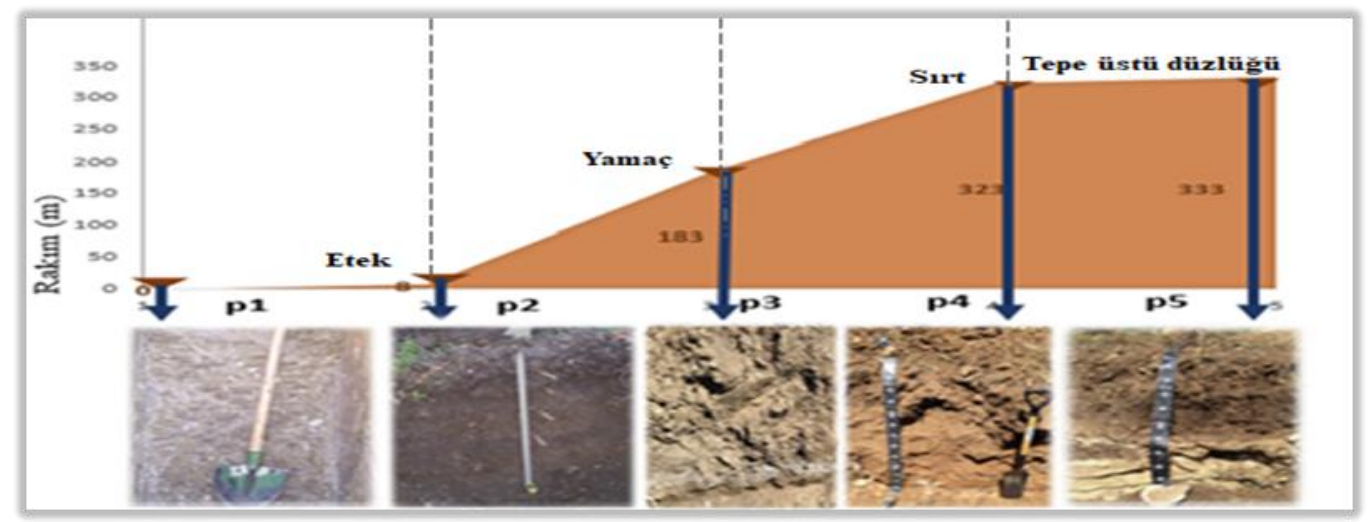

Şekil 2.Toprak profillerinin topoğrafik konumu ve görünümleri

\section{Laboratuvar analizleri}

Çalışmada toprak profilleri Soil Survey Division Staff, (2017)'de belirtilen kriterlere göre incelenmiş ve farklı derinliklerdeki horizonlardan 29 adet toprak örneği alınmıştır. Laboratuvar analizleri ile toprakların fiziksel, kimyasal ve bazı mineralojik özellikleri saptanmıştır. Toprak örneklerinde $\mathrm{pH}$ (1:2,5 toprak- su süspansiyonu), organik madde (Sağlam, 2008), kireç yüzdesi (Schlichting ve Blume 1966), katyon değişim kapasitesi-KDK Sodyum asetat ekstraksiyonu yöntemi ile (USDA, 1954), tekstür (Bouyoucos, 1951), C/N oranı (Kirsten, 1983) 'e göre belirlenmiştir. XRD ve SEM analizleri ÇOMÜ Merkez Laboratuvarında (ÇOBİLTUM), major oksit analizleri ise Kale Seramik (Çan) laboratuarında yapılmıştır. XRD analizleri, Harris, W. ve White, G.N., (2008) in belirttiği esaslara göre yürütülmüss olup PANakytical Empyrean cihazında $5^{\circ}-70^{\circ}(2 \theta)$ aralığında ölçüm alınmış ve veriler X'Pert HighScore Plus software yazılımında işlenmiş̧ir. SEM analizi White, G.N.,( 2008)' in belirttiği esaslara göre yürütülmüş ve yüzey görüntüleri JEOL JSM-7100F marka-modelindeki Taramalı Elektron Mikroskobu (FE-SEM) ile alınmış olup EDX spektrumları Oxford Instrument XMax marka-modelindeki dedektör kullanılarak ölçülmüştür. Örneklerin iletkenlik özelliklerini

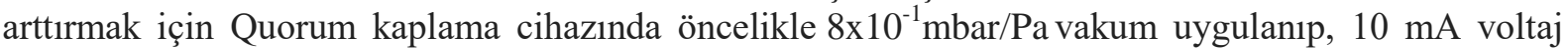
uygulanarak altın-paladyum (\%80-20) kaplama işlemi yapılmıştır.

\section{Bulgular ve Tartışma}

Toprakların meydana gelmesi, doğadaki diğer varlıkların oluşundan daha uzun zaman süreci aldığı gibi, daha karmaşık faktör ya da işlemlerin karşılıklı etkilerine dayanmaktadır. Belirli topoğrafik 
koşullar ve zaman dilimlerinde iklim ve canlıların ana materyal üzerindeki etkileri nedeniyle toprakta ve çevrede etki ve katkı dereceleri farklı bazı fiziksel, kimyasal ve biyolojik işlemler devam etmektedir. Bu faktör ya da işlemlerdeki en küçük farklılıkların kombinasyonu farklı ve benzersiz toprak karakteristiklerinin ortaya çıkmasına neden olmaktadır. Daha açık bir ifade ile örneğin yağış miktarındaki değişiklikler, fizyografyanın elementi olan topoğrafyanın değişmesi veya ana materyalin farklılaşması, kısa aralıklar içerisinde bile toprak karakteristiklerine yansımakta ve dolayısıyla birbirinden farklı özelliklere sahip topraklar oluşmaktadır. Nitekim, çalışma alanında topoğrafik ve drenaj koşullarındaki farklılıklar, toprak profilindeki horizon farklılaşmasını sağlayan işlemleri de (ilaveler, yer değiştirmeler, dönüşümler ve kayıplar) etkilemiştir. Bunun sonucunda inceleme alanı toprakları farklı karakteristikler içeren birbirinden farklı taksonomik kategorilerde sınıflandırılmıştır.

\section{Toprak Örneklerinin Fiziksel ve Kimyasal Özellikleri}

Toprak örneklerinin bazı fiziksel ve kimyasal analiz sonuçları Çizelge 1'de sunulmuştur.

Çizelge 1. Toprak profillerinin bazı fiziksel ve kimyasal analiz sonuçları

\begin{tabular}{|c|c|c|c|c|c|c|c|c|c|c|c|c|}
\hline$\underline{\mathbf{P}}$ & Horizon & $\begin{array}{r}\text { Derinlik } \\
(\mathrm{cm})\end{array}$ & $\begin{array}{r}\mathbf{p H} \\
(1: 2,5 \\
\text { top/su })\end{array}$ & $\begin{array}{r}\mathbf{E C} \\
(\mathrm{d} S / \mathrm{m}) \\
\end{array}$ & $\begin{array}{r}\text { KDK } \\
\frac{(\mathrm{cmol} / \mathrm{k}}{\left.\mathrm{g}^{-1}\right)}\end{array}$ & $\begin{array}{r}\text { Kireç } \\
(\%)\end{array}$ & $\begin{array}{l}\mathbf{O M} \\
(\%) \\
\end{array}$ & $\underline{\mathrm{C} / \mathrm{N}}$ & $\begin{array}{r}\text { Kum } \\
(\%)\end{array}$ & $\begin{array}{l}\text { Silt } \\
(\%)\end{array}$ & $\begin{array}{l}\text { Kil } \\
(\%) \\
\end{array}$ & Bünye \\
\hline \multirow{7}{*}{1} & Ap & $0-21$ & 7.80 & 0.24 & 39.90 & 13.07 & 2.66 & & 55.1 & 12.8 & 32.1 & SCL \\
\hline & $\mathrm{A} 2$ & $21-36$ & 7.84 & 0.25 & 39.05 & 13.63 & 2.17 & & 54.6 & 8.7 & 36.7 & SC \\
\hline & $\mathrm{Bw}$ & $36-57$ & 7.86 & 0.47 & 29.44 & 10.20 & 1.03 & & 65.7 & 8.6 & 25.7 & SCL \\
\hline & $\mathrm{BC}$ & $57-86$ & 7.90 & 0.43 & 36.30 & 15.44 & 1.97 & & 55.1 & 4.2 & 40.7 & SC \\
\hline & Ck1 & $86-108$ & 7.99 & 0.26 & 35.05 & 24.25 & 0.54 & & 38.2 & 19.1 & 42.7 & $\mathrm{C}$ \\
\hline & $\mathrm{Ck} 2$ & $108-190$ & 8.11 & 0.25 & 36.41 & 22.42 & 0.76 & & 40.0 & 17.1 & 42.9 & $\mathrm{C}$ \\
\hline & $\mathrm{O}$ & $0-5$ & 7,1 & 0,69 & 70,86 & 5,37 & 15,9 & & 68,60 & 15,71 & 15,73 & SL \\
\hline \multirow{5}{*}{2} & A1 & $5-18$ & 7,48 & 0,28 & 41,21 & 9,51 & 8,67 & & 42,53 & 19,92 & 37,64 & CL \\
\hline & A2 & $18-32$ & 7,55 & 0,13 & 49,34 & 16,2 & 3,58 & & 38,63 & 21,96 & 39,57 & CL \\
\hline & $\mathrm{AB}$ & $32-48$ & 7,71 & 0,29 & 46,68 & 22,7 & 2,05 & & 40,92 & 19,64 & 39,58 & CL \\
\hline & $\mathrm{Bw}$ & $48-75$ & 7,85 & 0,24 & 41,78 & 27,9 & 1,32 & & 43,41 & 15,22 & 41,49 & $\mathrm{C}$ \\
\hline & $\mathrm{C}$ & $75+$ & - & - & - & - & - & & - & - & - & - \\
\hline \multirow{6}{*}{3} & Ap & $0-12$ & 7,72 & 0,23 & 41,17 & 4,97 & 6,97 & 22 & 27,58 & 29,51 & 42,91 & CL \\
\hline & Ass1 & $12-35$ & 7,73 & 0,21 & 42,60 & 17,60 & 2,46 & & 27,42 & 23,24 & 49,34 & $\mathrm{C}$ \\
\hline & Ass2 & $35-52$ & 7,76 & 0,25 & 43,00 & 14,08 & 0,75 & 127 & 27,19 & 16,96 & 55,85 & $\mathrm{C}$ \\
\hline & Ass3 & $52-75$ & 7,87 & 0,27 & 40,85 & 13,02 & 1,90 & & 24,91 & 21,24 & 53,85 & C \\
\hline & $\mathrm{AC}$ & $75-85$ & 7,74 & 0,49 & 40,00 & 16,01 & 0,20 & & 22,45 & 10,66 & 66,89 & $\mathrm{C}$ \\
\hline & $\mathrm{Ck}$ & $85+$ & 7,66 & 0,51 & 36,95 & 17,95 & 0,13 & & 23,37 & 8,80 & 67,83 & C \\
\hline \multirow{6}{*}{4} & $\mathrm{~A} 1$ & $0-19$ & 7,69 & 0,22 & 40,85 & 3,34 & 6,50 & 24 & 42,33 & 21,02 & 36,59 & CL \\
\hline & $\mathrm{AC}$ & $19-30$ & 7,68 & 0,21 & 32,15 & 31,15 & 4,80 & 266 & 40,91 & 23,76 & 35,33 & $\mathrm{CL}$ \\
\hline & $\mathrm{C} 1$ & $30-55$ & 7,88 & 0,13 & 26,05 & 44,88 & 0,13 & & 39,98 & 42,93 & 17,09 & $\mathrm{~L}$ \\
\hline & $\mathrm{C} 2$ & $55-95$ & 8,02 & 0,11 & 15,20 & 42,68 & 0,12 & & 78,98 & 2,03 & 18,99 & SL \\
\hline & $2 \mathrm{C}$ & $95-125$ & 7,95 & 0,13 & 26,04 & 40,13 & 1,35 & & 68,89 & 16,93 & 14,18 & SL \\
\hline & $2 \mathrm{Cr}$ & $125+$ & 7,96 & 0,13 & 23,00 & 41,13 & 1,79 & & 82,98 & 2,04 & 14,98 & LS \\
\hline \multirow{5}{*}{5} & A1 & $0-12$ & 7,8 & 0,18 & 30,65 & 39,95 & 7,50 & 48 & 58,02 & 18,56 & 23,42 & SCL \\
\hline & A2 & $12-27$ & 7,91 & 0,23 & 28,08 & 39,24 & 5,50 & 53 & 76,59 & 2,06 & 21,35 & SCL \\
\hline & $\mathrm{Bw}$ & $27-46$ & 7,68 & 0,32 & 26,66 & 28,16 & 4,80 & & 57,09 & 20,59 & 24,32 & SCL \\
\hline & $\mathrm{BC}$ & $46-54$ & 7,93 & 0,22 & 23,90 & 50,86 & 2,50 & & 64,65 & 12,22 & 23,13 & SCL \\
\hline & $\mathrm{Cr}$ & 54-85 & 8,11 & 0,14 & 12,60 & 42,71 & 1,50 & & 83,17 & 2,02 & 12,22 & SL \\
\hline
\end{tabular}

Çizelge 1 de görüldüğü gibi toprak profillerinde genel olarak kumlu kil ve kil tekstür sınıfı baskındır. Toprak asitliği $(\mathrm{pH})$ genellikle 7 ile 8 arasında değişmekte olup Richards, (1954) ile 
Grewelling ve Peech, (1960)'e göre hafif alkalin olarak bulunmuştur. Organik madde içeriği ise \% 0,12 ile 15,9 arasında değişmektedir. Organik madde miktarı Smith ve Weldon, (1941)'a göre değerlendirildiğinde 2 numaralı profilde oldukça yüksek (\%15.9) miktardadır. Katyon değişim kapasitesi (KDK) değerleri kil içeriğinin yüksek olduğu 3 numaralı profilde $\left(43 \mathrm{cmol} \mathrm{kg}^{-1}\right)$, organik madde içeriğinin yüksek olduğu 2 nolu profilin $O$ horizonunda $70 \mathrm{cmol} \mathrm{kg}^{-1}$ olarak saptanmıştır. Yüksel ve Ekinci, (2019) Meriç Nehri teraslarında yapılan profil örneklemesinde toprakların KDK değerlerinin kil kapsamına göre değişiklik gösterdiğini, kil tekstüre sahip bir profilde KDK değerinin $65,26 \mathrm{cmol} \mathrm{kg}^{1}$ a kadar yükseldiğini belirlemişlerdir. Kireç miktarları Ülgen ve Yurtsever, (1995)'e göre değerlendirildiğinde tüm profillerin kireçli, orta kireçli sınıfında yer aldığı görülmüştür.

\section{Toprak Örneklerinin Bazı Morfolojik, Mineralojik ve Jeokimyasal Özellikleri}

İnceleme alanı topraklarındaki oksit içerikleri Çizelge 2 de verilmiştir. $\mathrm{SiO}_{2}$ içeriği tüm profillerde $\% 26,24-\% 66,4$ ve $\mathrm{Al}_{2} \mathrm{O}_{3}$ içeriği ise $\% 4,24$ ve \%13,64 arasında değişmektedir. Topraktaki $\mathrm{Al}$ doğrudan kil dağılımı ile ilişkilidir ve olgun topraklarda $\mathrm{Al}_{2} \mathrm{O}_{3}$ miktarı artmaktadır. $\mathrm{Fe}_{2} \mathrm{O}_{3}$ içeriği ise tüm profillerde $\% 0,97-5,05$ arasında, $\% \mathrm{CaO}$ miktarı ise $\% 4,91-29,25$ arasında değişmektedir.

Çizelge 2. Toprak profillerinin major oksit analiz sonuçları

\begin{tabular}{|c|c|c|c|c|c|c|c|c|c|c|}
\hline Profil No & Horizon & $\begin{array}{l}\text { A.Z. } \\
(\%)\end{array}$ & $\begin{array}{r}\mathrm{SiO}_{2} \\
(\%)\end{array}$ & $\begin{array}{r}\mathrm{Al}_{2} \mathrm{O} \\
(\%)\end{array}$ & $\begin{array}{r}\mathrm{TiO}_{2} \\
(\%)\end{array}$ & $\begin{array}{r}\mathrm{Fe}_{2} \mathrm{O}_{3} \\
(\%)\end{array}$ & $\begin{array}{r}\mathrm{CaO} \\
(\%)\end{array}$ & $\begin{array}{r}\mathrm{MgO} \\
(\%)\end{array}$ & $\begin{array}{r}\mathrm{Na}_{2} \mathrm{O} \\
(\%)\end{array}$ & $\begin{array}{l}\mathrm{K}_{2} \mathrm{O} \\
(\%)\end{array}$ \\
\hline \multirow{4}{*}{ P1 } & Ap & 13,90 & 55,55 & 11,47 & 0,73 & 3,84 & 9,30 & 2,06 & 0,92 & 1,95 \\
\hline & $\mathrm{Bw}$ & 13,64 & 55,79 & 11,19 & 0,64 & 3,67 & 9,99 & 1,78 & 1,03 & 1,94 \\
\hline & $\mathrm{Ck}$ & 15,79 & 51,73 & 10,97 & 0,67 & 3,83 & 11,27 & 2,85 & 0,80 & 1,77 \\
\hline & Ap & 8,81 & 66,4 & 12,16 & 0,44 & 2,88 & 6,81 & 0,61 & 0,24 & 1,58 \\
\hline \multirow[t]{2}{*}{ P3 } & Ass 3 & 12,78 & 56,23 & 12,68 & 0,80 & 4,51 & 8,79 & 1,79 & 0,64 & 1,50 \\
\hline & $\mathrm{Ck}$ & 12,25 & 55,44 & 13,64 & 0,86 & 5,10 & 8,01 & 2,19 & 0,64 & 1,57 \\
\hline \multirow[t]{3}{*}{$\mathrm{P} 4$} & $\mathrm{~A}_{1}$ & 11,30 & 62,77 & 12,15 & 0,75 & 5,05 & 4,10 & 1,34 & 0,52 & 1,67 \\
\hline & $\mathrm{Ck}_{1}$ & 23,27 & 41,64 & 7,08 & 0,63 & 2,20 & 22,62 & 0,98 & 0,47 & 0,91 \\
\hline & $\mathrm{A}_{1}$ & 22,29 & 44,89 & 8,16 & 0,44 & 2,38 & 18,57 & 1,21 & 0,36 & 1,34 \\
\hline \multirow[t]{2}{*}{ P5 } & $\mathrm{Bw}$ & 22,31 & 47,14 & 8,39 & 0,44 & 2,40 & 16,05 & 1,06 & 0,46 & 1,42 \\
\hline & $\mathrm{Cr}$ & 32,73 & 26,25 & 4,24 & 0,19 & 0,97 & 29,25 & 5,09 & 0,36 & 0,70 \\
\hline
\end{tabular}

Profil 1 toprakları, arazinin üst kısımlarından taşınan killi materyallerin biriktiği, eğimin düz düze yakın olduğu (\%2) kolüviyal etek düzlüklerinde oluşmuştur. A-B-C horizon dizilimine sahip olup killi ve derin profil yapısındadır. Profilde kambik horizonun altında bir kalsik horizon (Ck) oluşumu mevcuttur. Wagner ve ark., (2007) toprak profillerinin horizonlarında $\mathrm{CaO}$ oranı $\% 1$ in altına düşerse o toprak profilinde dekalsifikasyon işleminin tamamlanmış olacağını belirtmektedir. $\mathrm{Bu}$ çalışmada incelenen tüm profillerde $\mathrm{CaO}$ oranı $\% 1$ in üzerinde bulunmuş olup dekalsifikasyon işleminin devam ettiği görülmektedir(Çizelge 2). Ekinci ve Yüksel, 2014, Meriç nehri teraslarında iki profilde $\mathrm{CaO}$ konsantrasyonunun $\% 1,13$ ve $\% 1,07$ olarak bulunmasını horizonlarda dekalsifikasyon işleminin devam ettiği şeklinde yorumlamışlardır.

Topraklarda kimyasal ayrışmanın yoğunluğu kimyasal ayrışma veya mineral ayrışma indisleri tarafından belirlenmektedir. Ayrışma düzeyinin saptanmasında çok sayıda indeks kullanılmaktadır. İncelenen toprak profillerine ait bazı jeokimyasal ayrışma oranları Çizelge 3 de gösterilmiştir. 
ÇOMÜ Zir. Fak. Derg. (COMU J. Agric. Fac.)

2021: 9 (1): 163-177

ISSN: $2147-8384$ / e-ISSN: 2564-6826

doi: $10.33202 /$ comuagri.887265

Çizelge 3.Toprak örneklerinin bazı jeokimyasal ayrışma oranları

\begin{tabular}{|c|c|c|c|c|c|c|}
\hline \multirow[b]{2}{*}{$\underline{\text { Profil }}$} & \multicolumn{3}{|c|}{ Derinlik } & \multicolumn{3}{|c|}{$\underline{\mathrm{SiO}}_{2} \underline{\mathrm{Al}}_{2} \underline{\mathrm{O}}_{3}$} \\
\hline & $\underline{\text { Horizon }}$ & $\underline{(\mathbf{c m})}$ & $\underline{\mathrm{SiO}}_{2} \underline{\underline{\mathrm{Al}_{2}}} \underline{\underline{\mathbf{O}}} \underline{3}_{3}$ & $\underline{\text { PIA }}$ & $\underline{+\mathrm{Fe}_{2}} \underline{\underline{O}}_{3}+\underline{\mathrm{TIO}}_{2}$ & $\underline{\text { CIA }}$ \\
\hline \multirow{3}{*}{ P1 } & Ap & $0-21$ & 4,73 & 75 & 3,66 & 69 \\
\hline & $\mathrm{Bw}$ & $36-57$ & 4,92 & 73 & 3,84 & 67 \\
\hline & $\mathrm{Ck}$ & $86-108$ & 4,63 & 77 & 3,57 & 71 \\
\hline \multirow{3}{*}{$\mathbf{P 3}$} & Ap & $0-12$ & 5,54 & 93 & 4,31 & 83 \\
\hline & Ass3 & $52-75$ & 4,35 & 84 & 3,33 & 78 \\
\hline & $\mathrm{Ck}$ & $85+$ & 3,96 & 85 & 3,01 & 78 \\
\hline \multirow[b]{2}{*}{ P4 } & $\mathrm{A} 1$ & $0-19$ & 5,36 & 85 & 3,92 & 77 \\
\hline & Ck1 & $30-55$ & 5,71 & 80 & 4,35 & 74 \\
\hline \multirow{3}{*}{ P5 } & $\mathrm{A} 1$ & $0-12$ & 5,38 & 85 & 4,26 & 75 \\
\hline & $\mathrm{Bw}$ & $27-46$ & 5,63 & 82 & 4,46 & 73 \\
\hline & $\mathrm{Cr}$ & $46-24$ & 6,25 & 73 & 5,21 & 68 \\
\hline
\end{tabular}

Profil 1'in X-Işını difraksiyon (XRD) analiz sonuçları Şekil 3 de sunulmuştur. Çizelgeden üm horizonlarda kuvars mineralinin fazla olduğu, bunun yanında albit, kalsit ve silikat minerallerinin de varlığı görülmektedir.
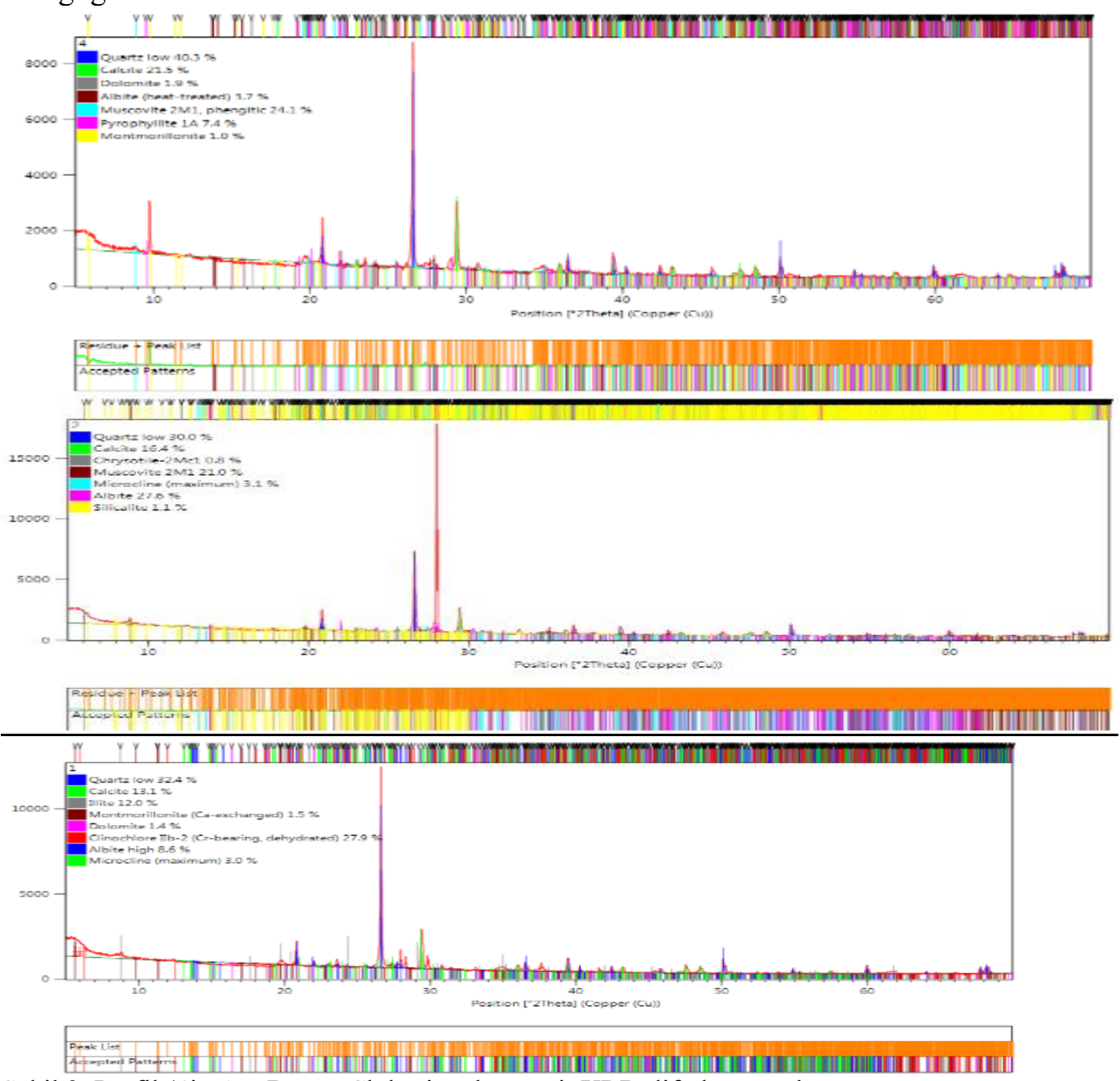

Şekil 3. Profil 1'in Ap, Bw ve Ck horizonlarına ait XRD difraktogramları 
a )

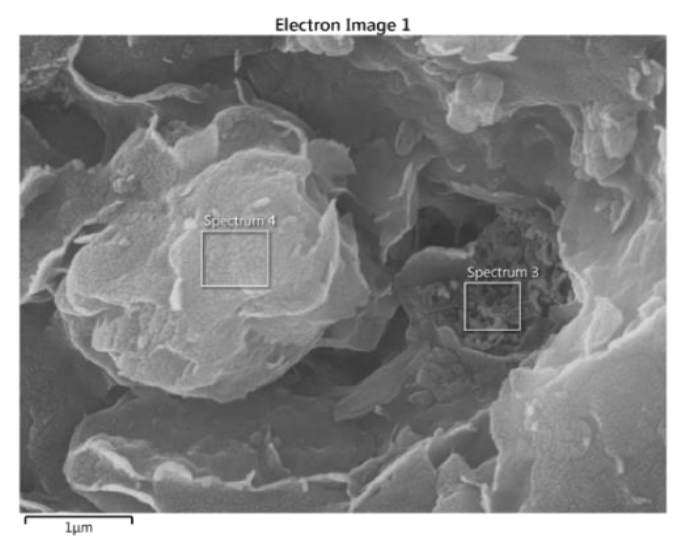

b)

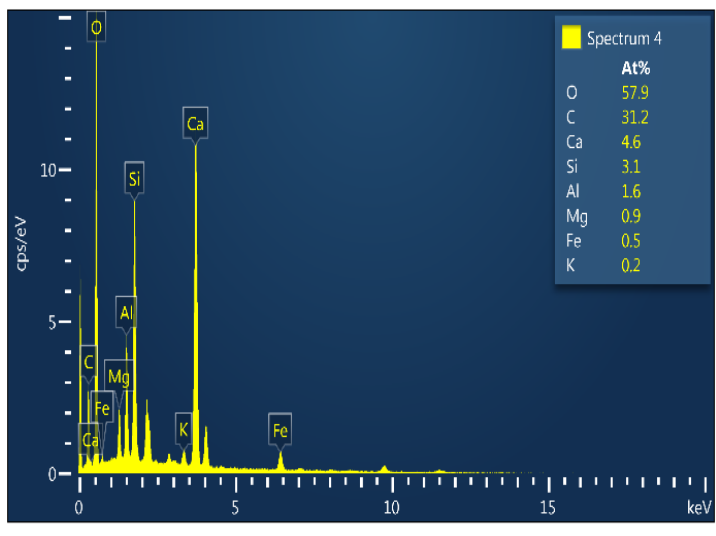

Şekil 4. Profil 1 'in Ap horizonuna ait SEM görüntüsü-kil oluşumu (a) ve 4 nolu spektrumun EDS analizi (b).

Profil 2 eğimin \%4-6 olduğu, kireç taşları üzerinde ve ormanlık alanda (maki) oluşmuştur. OA-B-C horizon dizilimine sahip olan bu profil, yüksek miktarda organik madde içeren $(\% 15,9)$ organik horizona $(\mathrm{Oe})$ sahiptir. Blok strüktüre sahip bir kambik $(\mathrm{Bw})$ horizonu bulunan profilde kil-tın tekstür hakimdir. Profildeki kil miktarının alt katmanlara doğru az da olsa arttığı görülmektedir (Çizelge 1). Horizonların X-Işını difraksiyon (XRD) analiz sonuçlarından da horizonlarda özellikle yüksek oranda illit $(\% 36,4)$ ve montmorillonit kil mineralleri saptanmıştır (Şekil 5). Söz konusu profilin yüksek oranda illit içermesi ana materyalinin kireç taşları olmasından kaynaklanmış olabilir. Nitekim Saatçi, (1964); Mitchell ve Irmak, (1957) kireç taşları üzerinde yaptıkları çalışmalarda yüksek oranda illit minerali saptamışlardır. 2 nolu profilin fundalık ve makilik bir alanda bulunması ve uzun süreden beri toprak işlemenin yapılmaması nedeniyle yüzeyde \%15,9 gibi yüksek bir organik madde içeriğine sahiptir. Bu özelliği nedeniyle koyu renkli ve katyon değişim kapasitesi (KDK) de (yüzeyde $70,86 \mathrm{cmolkg}^{-1}$ ) yüksektir (Çizelge 1). Söz konusu profil diğer fizikokimyasal ve mineralojik özellikleri bakımından yakın konumda olan 1 no'lu profil ile benzer karakterdedir.
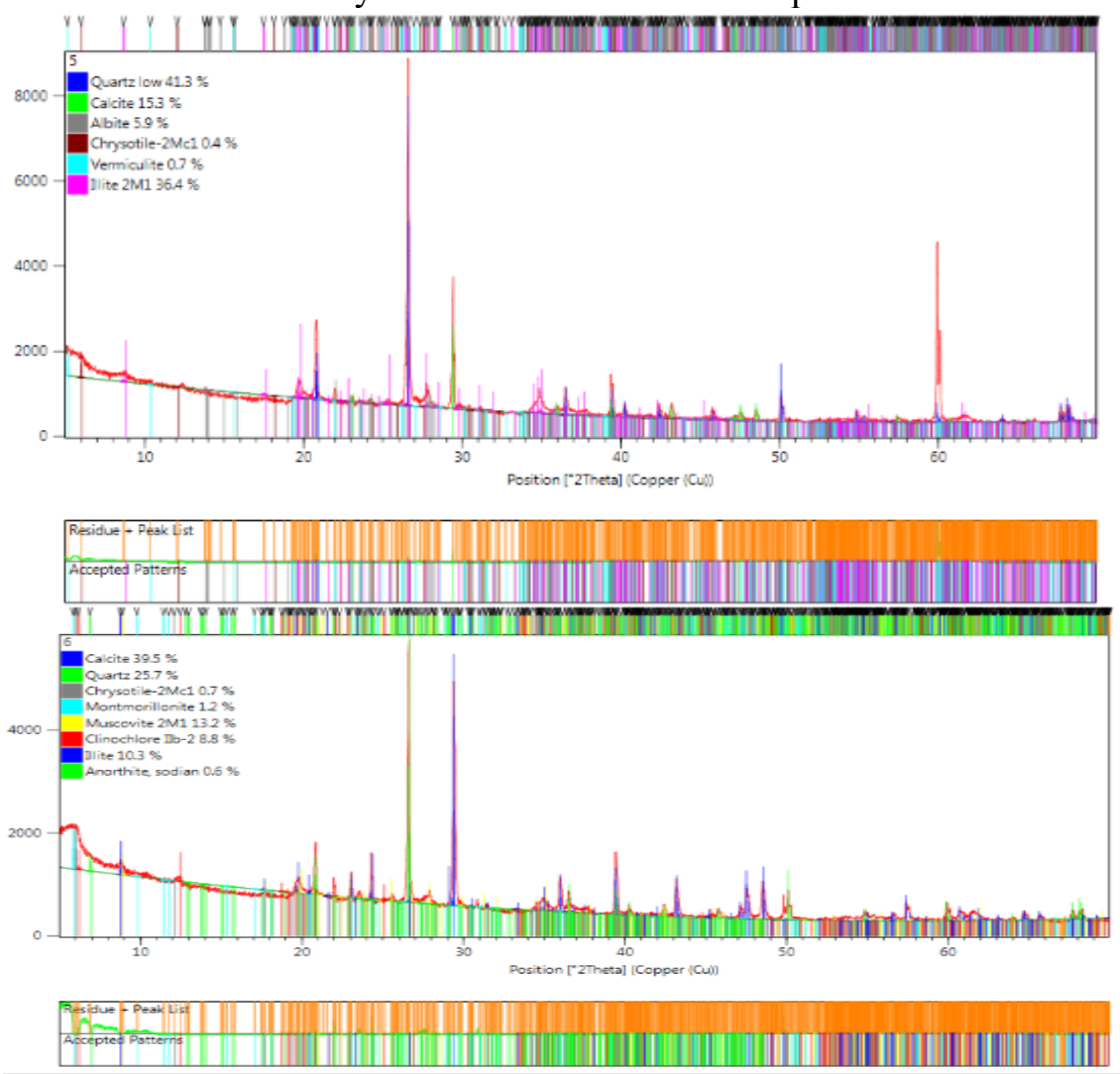

Şekil 5. Profil 2’nin A1 ve Bw horizonuna ait XRD difraktogramı 
Profil 3, profil 1 ve profil 2 ye göre daha yüksek rakımdaki eski yüksek deniz teraslarının hafiforta eğimli yamaçlarında yer almaktadır. Profilin bulunduğu kısımda, doğal bir teras konumu hakimdir (Şekil 2). Söz konusu toprak profili killi ve kireçli ana materyaller (marn) üzerinde oluşmuş, A-C horizon dizilimine sahip, orta- derin profil yapısına sahiptir. Ana materyalinin kireçli marn depozitleri olması nedeniyle profil boyunca kil miktarı yüksek bulunmuştur. Bunun yanında profil boyunca görülen çatlaklar ve parlak sürtünme yüzeyleri söz konusu profilde 2:1 tipi killerin varlığını göstermektedir. Nitekim XRD analizlerinde 3 no'lu profilin tüm horizonlarında 2:1 tipi kil mineralllerinden montmorillonit saptanmıştır (Şekil 6). Marn ve kireç taşı üzerinde oluşan topraklarda genellikle smektitik killer oluşmaktadır (Sayın, 1999).

Profil 3 horizonları 78-83 arasında bir CIA indeksi ile orta-ileri derecede ayrışmış topraklar sınıfında yer almaktadırlar. En fazla ayrışma CIA (83) Ap horizonunda görülmektedir. Nitekim plajioklas ayrışma oranı (PIA) değeri sözkonusu horizonda tüm horizonlar içerisinde en yüksek değerde (93) saptanmıştır (Çizelge 3). Bunun yanında bu horizonda $\mathrm{C} / \mathrm{N}$ oranı da diğerlerine göre dardır (22) ve bu durum söz konusu profilde, diğer profillere göre minerallerle birlikte organik maddenin de oldukça ayrıştığını göstermektedir. Organik madde mineral değişimi ve alterasyonunda çok önemli bir etmen olup toprak genesisinde oldukça önemlidir (Fox, 1995). Colman (1982), topraklarda $\mathrm{SiO}_{2} / \mathrm{Al}_{2} \mathrm{O}_{3}+\mathrm{Fe}_{2} \mathrm{O}_{3}+\mathrm{TiO}_{2}$ oranında bir azalmanın yerinde ayrışmanın (in situ) bir göstergesi olarak kabul edilebileceğini bildirmektedir. Bu çalışmada profil 3 de söz konusu oranın 4,31'den 3,01 'e düştüğü görülmektedir (Çizelge 3 ). Bu durum, incelenen profilde ayn1 zamanda yerinde ayrışma olayının varlığını da göstermektedir.
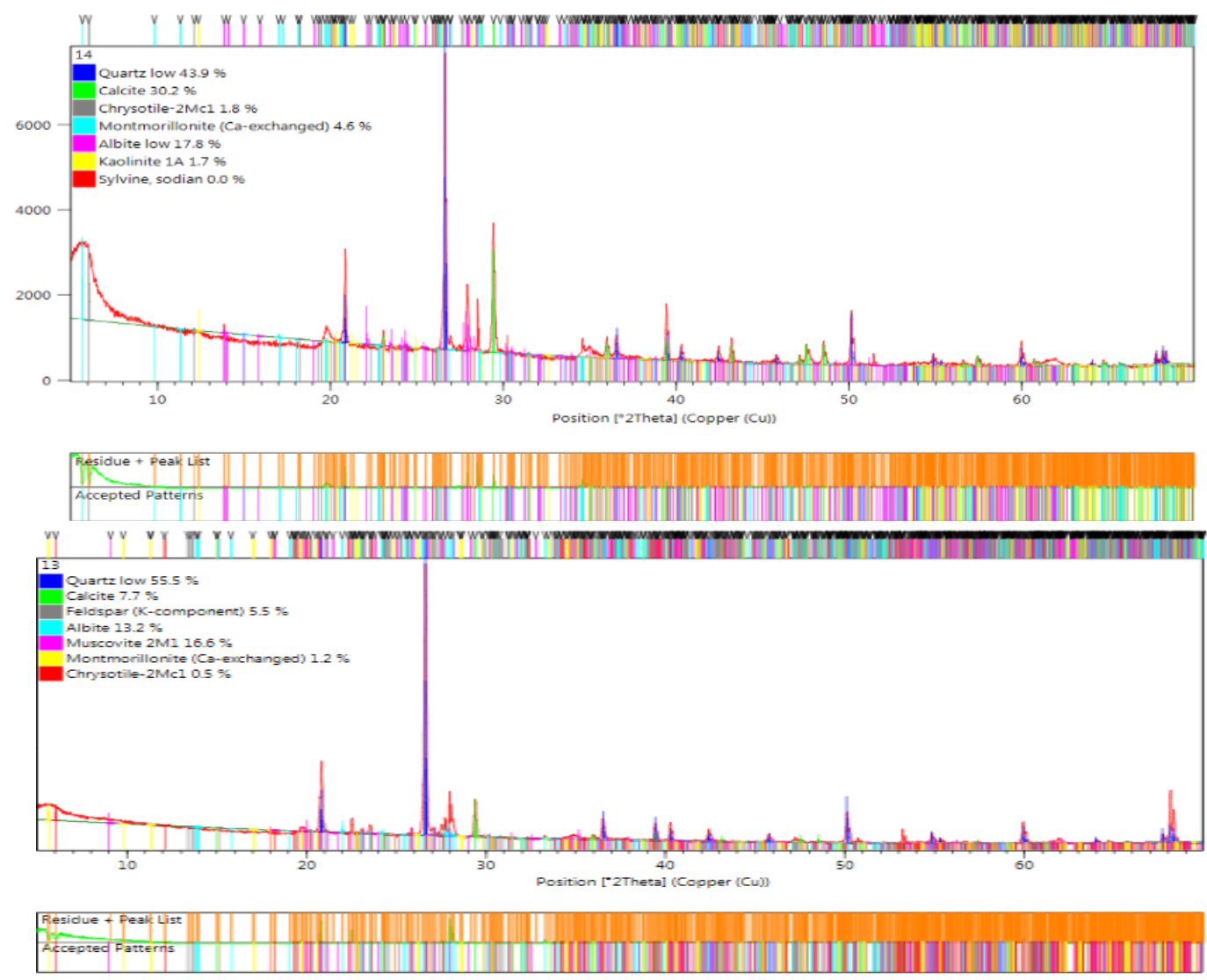


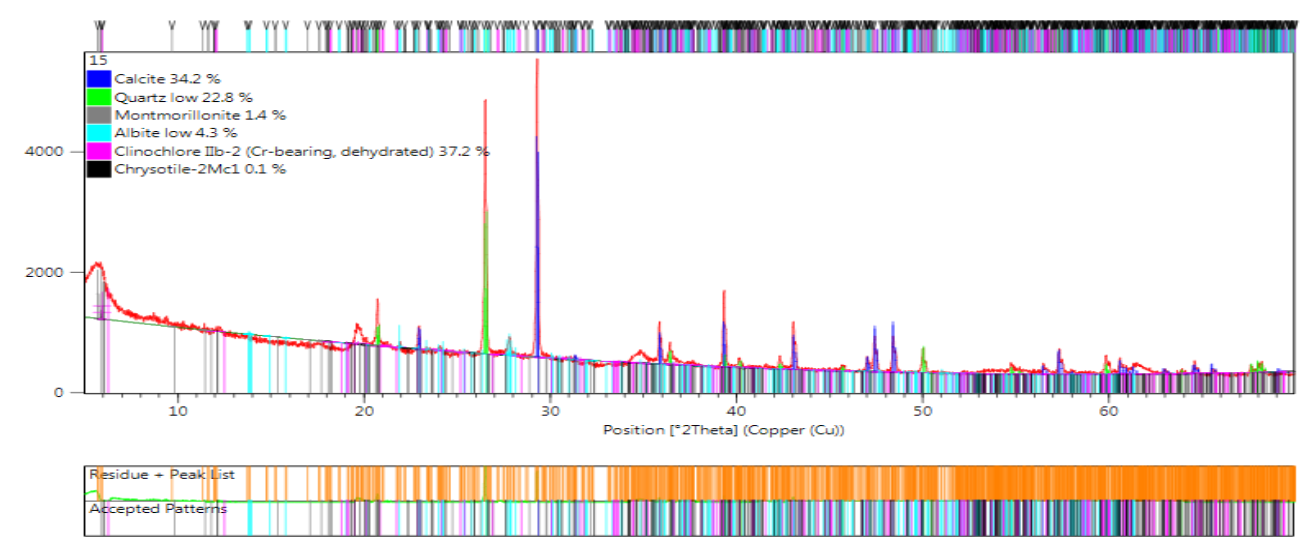

Şekil 6. Profil 3'ün Ap, Ass3 ve Ck horizonuna ait XRD difraktogramı

Profil 4, eğimin oldukça fazla olduğu (\%8-12) eski yüksek deniz teraslarının sırt-omuz konumunda, kireçli ve kili-kumlu ana materyaller üzerinde oluşmuş, orta-şiddetli erozyon etkisiyle sı̆̆ bir profil yapısına sahiptir. Bu nedenle profilde tanımlayıcı yüzey - yüzey altı horizonu bulunmamakta ve A-C horizon dizilimi görülmektedir. Üst horizonlarda killi tın, alt horizonlarda ise kumlu tın tekstür hakimdir. XRD analiz sonuçlarından anlaşılacağı üzere ana materyallerinde albit, muskovit ve kalsit gibi ana materyalden geçen mineraller fazladır. Ayrıca düşük sıcaklıklarda oluşan bir K-feldspat olan mikroklin de saptanmıştır. Bu mineral genellikle albit minerali ile birlikte bulunmaktadır (Kurt ve Arık, 2007). Ancak, atmosferik koşullara bağlı olarak yüzeyde bazı minerallerde ayrışma kısmen fazladır ve CIA indeksi 77 değeriyle orta ayrışmış sınıfında belirlenmiştir. Bu ayrışma profilde en yüksek oranda bulunan kalsit mineralinde daha yüksek oranda gerçekleşmiştir. Nitekim $\mathrm{C}$ horizonunda \%71,6 oranında bulunan kalsit minerali A1 horizonunda \%16,9 olarak saptanmıştır. (Şekil 7).
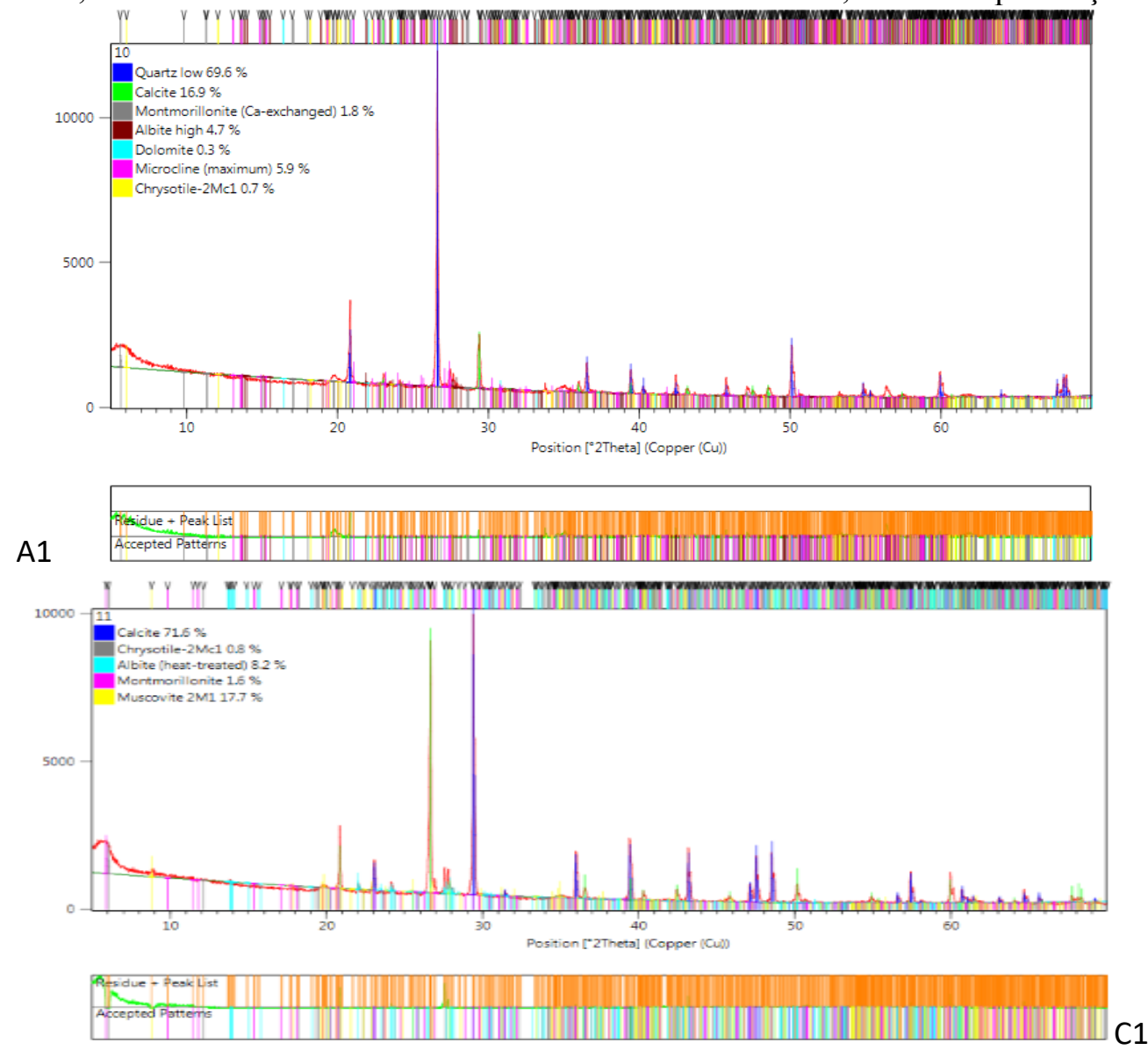

Şekil 7. Profil 4'ün A1 ve C1 horizonuna ait XRD difraktogramı 
Proil 5, eğimin \%3-4 olduğu eski yüksek deniz teraslarında, kireçli- kumlu depozitlerin yer aldığ1 tepe üstü düzlügünde (doruk-summit) oluşmuştur (Şekil 2). A-B-C horizon dizilimine sahip profilin en üst katmanında koyu renkli, yüksek oranda organik madde ile karışmış mineral A1 horizonu bulunmaktadır. A horizonunun altında ise zayıf gelişen, blok sütrüktüre sahip ve kısmen kil artışının görüldüğü kambik horizon bulunmaktadır. Profilde hakim tekstür kumlu kil tındır.

Horizonların X-Işını difraksiyon (XRD) analiz sonuçlarından da görüldüğü üzere tüm horizonlarda en fazla kuvars ve kalsit mineraline rastlanmaktadır. Bunun yanında albit, montmorillonit ve muskovit gibi minerallere de mevcuttur (Şekil 8). Profil 5 in kambik horizonundaki silika ve kil minerallerinin SEM ve EDS görüntüleri (Şekil 9) da sunulmuştur. Profil 5 CIA indeksine göre (68-75) orta derecede ayrışmış sınıfındadır. $\mathrm{SiO}_{2} / \mathrm{Al}_{2} \mathrm{O}_{3}$ oranlarında alta doğru bir artışın olması (yıkanma - kil taşınmasının olmaması) yerinde ayrışmanın (in-situ) varlığını göstermektedir (Çizelge 3).
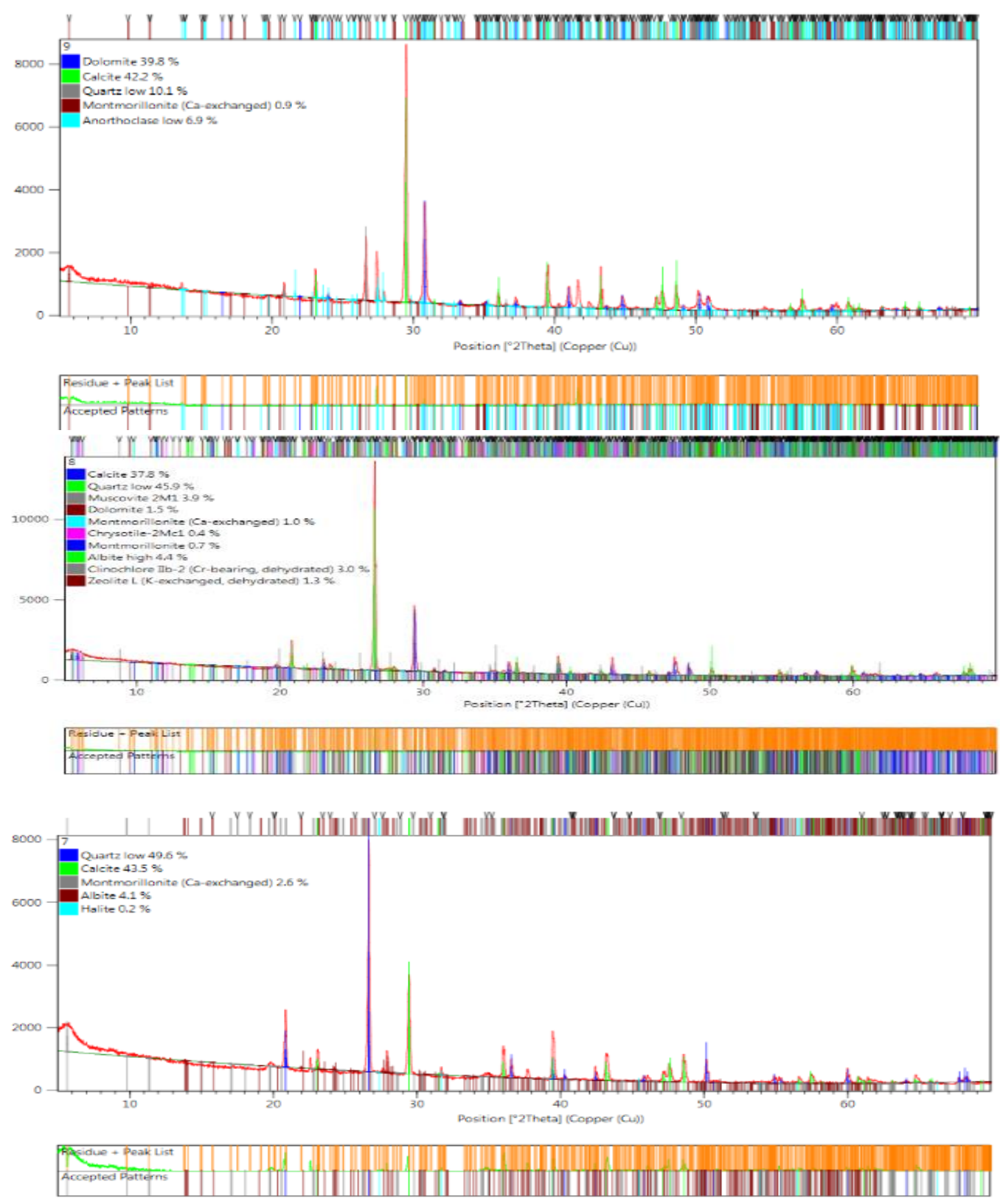

Şekil 8. Profil 5'in A1, Bw ve Cr horizonuna ait XRD difraktogramı 

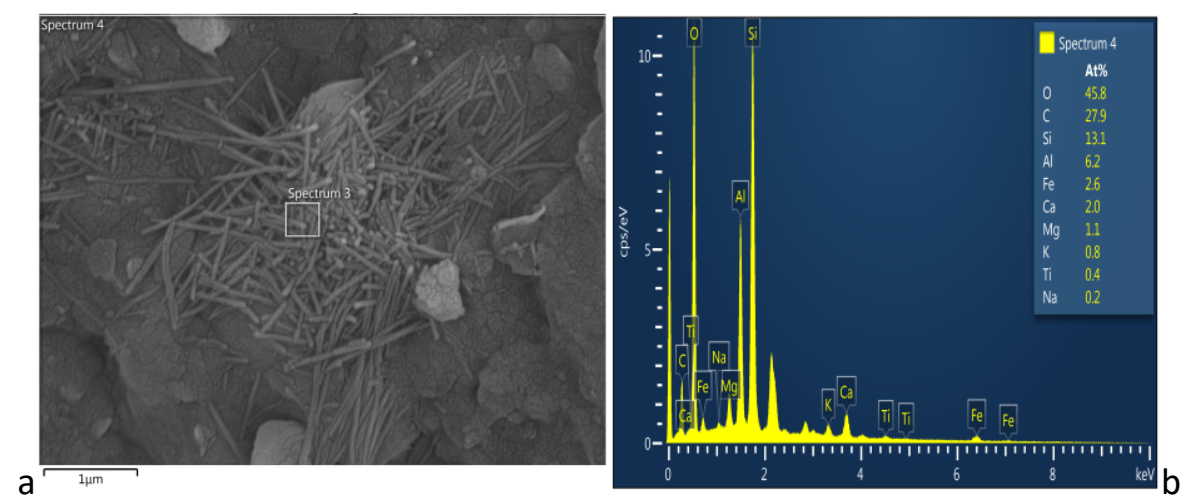

Şekil 9. Profil 5'in Bw horizonuna ait SEM görüntüsü (spektrum 3 ve 4) üzerindeki silika etrafındaki kil oluşumu (a), spektrum 4'ün EDS mikrografları (b).

partikülleri ve

\section{Toprakların sınıflandırılması}

Çalış1lan profil topraklarının Toprak Taksonomisi (Soil Surey Staff, 2014) ve WRB toprak sınıflandırma sistemine (IUSS, 2014) göre sınıflandırması Çizelge 4'de verilmiştir. Çalışma alanında toprak nem rejimi xeric, toprak sıcaklık rejimi ise thermictir. Suluca-Kocaveliköy katenasında eğimin en az olduğu noktadan itibaren üst yamaçlar ve omuz kısmına doğru sırasıyla Inceptisol, Mollisol, Vertisol ve Entisol ordoları saptanmıştır. Doruk noktasındaki tepe üstü düzlügüünde ise erozyonun daha az olması ve bitki örtüsünün fundalık olması nedeniyle yüksek oranda saptanan organik maddeye bağlı olarak Mollisol ordosuna ait topraklar belirlenmiştir. WRB sistemine göre yapılan sınıflandırmada ise incelenen toprak profilleri calcisols, phaozems, leptosols, vertisols ve cambisols referans toprak gruplarında sınıflandırılmıştır.

Çizelge 4. Çalışma alanı topraklarının sınıflandırılması

Toprak Taksonomisi-2014

$\underline{\text { WRB-2014 }}$

\begin{tabular}{clllll}
$\underline{\text { Profil }}$ & Ordo & Alt ordo & Büyük grup & $\underline{\text { Alt grup }}$ & $\underline{\text { Referans toprak grubu }}$ \\
1 & Inceptisol & Xerepts & Calcixerepts & $\begin{array}{l}\text { Vertic } \\
\text { Calcixerepts }\end{array}$ & Cambic Calcisols \\
2 & Mollisol & Xerolls & Haploxerolls & $\begin{array}{l}\text { Calcic } \\
\text { Haploxerolls } \\
\text { Typic }\end{array}$ & Cambic Phaeozems \\
3 & Vertisol & Xererts & Calcixererts & $\begin{array}{l}\text { Calcixererts } \\
\text { Calcic Mollic Vertisols } \\
\text { (Calcaric) }\end{array}$ \\
4 & Entisol & Orthents & Xerorthent & $\begin{array}{l}\text { Lithic } \\
\text { Xerorthents }\end{array}$ & $\begin{array}{l}\text { Rendzic, Calcaric } \\
\text { Leptosols }\end{array}$ \\
5 & Mollisol & Xerolls & Durixerolles & $\begin{array}{l}\text { Haploxerollic } \\
\text { Durixerols }\end{array}$ & $\begin{array}{l}\text { Petroduric, Cambic } \\
\text { Phaeozems }\end{array}$ \\
\hline
\end{tabular}

\section{Sonuçlar}

Suluca-Kocaveliköy (Lapseki-Çanakkale) katenasında yürütülen bu çalışma, genellikle kireçli ve killi, kısmen kumlu eski deniz teraslarının farklı eğim ve yüksekliğe sahip arazi konumlarında gerçekleştirilmiştir. Arazi peyzajının oluşumunda eğimle birlikte erozyon, kolüviyal birikimler ve çamur akıntıları etkili olmuştur. Profillerin bulunduğu konumlar eğimi \%1-2 olduğu kolüviyal alt etek düzü (toeslope - P1), eğimin \%2-3 olduğu kolüviyal alt etek (footslope- P2), taşınmış materyallerin birikim gösterdiği orta eğimli doğal teraslar (midslope) -P3), \%8-12 dişbükey eğimli yamaç- omuz (backslope-shoulder -P4) ve tepe üstü düzlügünden (zirve -summit) oluşmaktadır. Toprak derinliği alt düzlüklerde ortalama $80 \mathrm{~cm}$ nin üzerinde iken erozyonun şiddetli olduğu omuz kısmında $30 \mathrm{~cm}$ kadardir.

Alt ve orta eğimde (toeslope,footslope ve midslope) oluşmuş toprakların strüktürü sı̆g ve erozyon etkisi görülen üst eğimdekilere göre daha kuvvetlidir.Orta eğimde doğal teraslar üzerinde genellikle marn üzerinde oluşmuş 3 nolu profilin tüm horizonları \%40 tan fazla kil içeriğine sahiptir. 
Bu kısımda topoğrafik yapı toprağa su girişine izin vermesi nedeniyle özellikle kimyasal ayrışmanın hızı daha fazladır. Alt kısımlardaki (toeslope,footslope) 1 ve 3 nolu profiller \%30-40 arasinda, tepe düzlügünde oluşmuş 5 nolu profil \%20-30 arasında, ve erozyon etkisinde olan (backslope-shoulder) 4 nolu profil ise $\% 20$ den daha az kil içermektedir. Buna bağlı olarak ve 3 nolu profil toprakları $40 \mathrm{cmolkg}^{-1}$ dan daha yüksek bir katyon değişim kapasitesine (KDK) sahiptir. Alt kısımlarda oluşan 1 ve 2 nolu profil topraklarının rengi genellikle koyu grimsi kahve, 3 nolu profil koyu kahverengidir. Üst kısımda eğimin fazla olduğu özellikle 4 nolu profilde ise erozyonun da etkisiyle kireçli ana materyaller yüzeye yakın konumdadır. Bu nedenle toprak rengi oldukça açık (sarımsı kahverengi) tondadır. Bu profiller alt kısımdaki profillerden daha yüksek oranda ( $>\% 30)$ kireç içermektedir.

Alt düzlüklerde oluşmuş profil 1 ve 2 nin X-Işını difraksiyon (XRD) analiz sonuçları, tüm horizonlarda kuvars mineralinin fazla olduğu, bunun yanında albit, kalsit ve silikat minerallerinin de varlığını göstermektedir. Profil boyunca farklı minerallere rastlanması ve derinlikle bu mineral oranlarının düzensiz olarak değişmesi söz konusu profillerin yukarı kısımlardan çamur akıntısı veya kolüviyal taşınmayla gelen materyal taşınma ve yı̆̆ılmalarından etkilendiğini göstermektedir. Buna karşın 1 ve 2 no lu profile göre daha yüksek rakımdaki yüksek deniz teraslarının hafif-orta eğimli yamaçlarında yer alan profil 3, doğal bir teras konumunda bulunması ve marn üzerinde oluşması nedeniyle kil içerüi yüksektir ve orta- derin profil yapısına sahiptir. Profil boyunca görülen çatlaklar ve sürtünme yüzeyleri söz konusu profilde 2:1 tipi killerin varlığını göstermektedir. Nitekim XRD analizlerinde 3 no'lu profilin tüm horizonlarında 2:1 tipi kil minerallerinden montmorillonit saptanmıştır. Profil 4 ise, eğimin oldukça fazla olduğu (\%8-12) eski yüksek deniz teraslarının sırtomuz konumunda, kireçli ve killi-kumlu materyaller üzerinde oluşmuş, orta-şiddetli erozyon etkisiyle sı $\breve{g}$ bir profil yapısına sahiptir. XRD analiz sonuçlarına göre ana materyallerinde saptanan albit, muskovit ve kalsit gibi ana materyalden geçen minerallerin fazlalığı ayrışmanın düşük olduğunu göstermektedir. Eğimin \%3-4 olduğu eski yüksek deniz teraslarında, kireçli- kumlu depozitlerin yer aldığ 1 tepe üstü düzlüğünde (doruk-summit) oluşan profil 5'in en üst katmanında koyu renkli, yüksek oranda organik madde ile karışmış mineral A1 horizonu bulunmaktadır. A horizonunun altında ise zayıf gelişen, blok sütrüktüre sahip ve kısmen kil artışının görüldüğü kambik horizon bulunmaktadır. $\mathrm{Bu}$ horizonda yerinde ayrışma ile kil oluşumu ayrışma indeksleri ile de doğrulanmıştır. Horizonların X-Işını difraksiyon (XRD) analiz sonuçlarından da görüldügü üzere tüm horizonlarda en fazla kuvars ve kalsit ile albit, montmorillonit ve muskovit gibi minerallere de rastlanmıştır.

Suluca-Kocaveliköy katenasında düşük eğimden üst yamaçlar ve omuz kısmına doğru sırasıyla inceptisol, mollisol, vertisol ve entisol ordoları belirlenmiştir. Doruk noktasındaki tepe üstü düzlüğünde ise erozyonun daha az olması ve bitki örtüsünün fundalık olması nedeniyle yüzeyde yüksek orandaki organik maddeye bağlı olarak mollisol ordosu bulunmaktadır. Çalışma sonucunda dört farklı toprak ordosu saptanmıştır. Bu durum, benzer iklim ve ana materyale sahip SulucaKocaveliköy katenasında, topoğrafik yapı ve drenaj faktörünün değişmesi ile yaklaşık 4 km gibi kısa bir mesafede bile farklı toprakların oluşabileceğini ortaya koymaktadır.

\section{Teşekkür}

$\mathrm{Bu}$ çalışma 1.yazarın yüksek lisans tez çalışmasından üretilmiştir. Çalışmaya; FHD-2018-1430 numaralı proje kapsamında destek veren Çanakkale Onsekiz Mart Üniversitesi Bilimsel Araştırma Projeleri Koordinasyon Birimine, araştırmanın oksit analizlerini gerçekleştiren kimya mühendisi Sayın Elif BAYKAL'a, XRD ve SEM analizlerini yapan ÇOMÜ ÇOBİLTUM yöneticilerine ve laboratuvar personeline, çeşitli toprak analizlerinde yardımcı olan Toprak Bilimi ve Bitki Besleme Bölümünden Dr. Arş. Gör. Remzi İLAY ve Dr. Arş. Gör. Gizem AKSU'ya, çalışma süreci boyunca yardımlarını gördügümüz Sadiye Tuğçe EREN ve Fatma Funda BAŞARLAR'a katkılarından dolayı teşekkürü bir borç biliriz.

\section{Kaynaklar}

Anonim, 1996. Soil Science Terms. SSSA, Inc. Wisconsin, USA.

Anonim, 1999. Çanakkale İli Arazi Varlığı. T.C. Başbakanlık Köy Hizmetleri Genel Müdürlüğü Yay. Rapor no:17. Ankara.

Applegarth, M And Dahms D.E., 2001. Soil catenas of calcereous tills, Whiskey Basin, Wyoming, USA. Catena. 42: 17-38.

Atabey, E., Ilgar A., ve Sakıtaş A., 2004. Çanakkale Havzasının ot-rta-üst miyosen stratigrafisi, Çanakkale, KB Türkiye, MTA Dergisi. 1: 29-97. 
Başarlar, F.F. ve Ekinci, H., 2019. Bayramiç-Çan arası farklı jeolojik ve jeomorfolojik araziler üzerinde oluşmuş toprakların özellikleri ve sınıflandırılması. ÇOMÜ Zir. Fak. Derg. (COMU J. Agric. Fac.). 7 (1): 69-80.

Bouyoucos, G.S., 1951. A recalibration of the hydrometer methods for making mechanical anlysis of soil Agron. Jour. 43.

Colman, S. M., 1982. Chemical weathering of basalts and andesites; evidence from weathering rinds (No. 1246). USGPO.

Dent, D., Young, A., 1981. Soil survey and land evaluation. George Allen \& Unwin (Publishers) Ltd. 40 Museum Street, London WC1A1LU, UK. 278p.

DMİ, 2016. Meteoroloji Genel Müdürlüğü (DMI). Çanakkale www.mgm.gov.tr/ veridegerlendirme/ il-ve-ilceler istatistik. aspx? $\mathrm{m}=$ Çanakkale

Ekinci, H., Yüksel, O., 2014. Soil formation on terraces with different elevations in meric catchment. 9th international soil science congress on "the soul of soil and civilization". October 14-16, 2014. Side, Antalya, Turkey

FAO, 1976. A Famework for land evaluation. FAO Soils Bulletin. 32(72).

Fox, T.R., 1995. The influence of low-molecular-weight organic acids on properties and processes in forest soils. in: Mcfee, W.W., Kelly, J. M. (Eds.), Carbon forms and functions in forest soils. soil science society of american, madison, WI, Pp: 43-62.

Grewelling, T., Peech M., 1960. Chemical soil test. Cornell Univ. Agr. Expt. Sta. Bull. No 960.

Güngördü, M., 1993. Güney Marmara Bölümünün (Batı Kesimi) Bitki Coğrafyası. İstanbul Üniversitesi.

Harris, W., White, G.N., 2008. X-Ray Diffraction techniques for soil mineral identification. Soil Science Society of America. 677 S. $\quad$ Segoe Road, Madison, WI 53711, USA. In: Ulery, A.L. and Drees, L.R. Ed,Method of Soil Analysis. Part 5. Mineralogical Methods. SSSA Book Series, no.5.

IUSS Working Group, WRB., 2015. world reference base for soil resources 2014, update 2015 international soil classification system for naming soils and creating legends for soil maps. World Soil Resources. FAO, Rome. Reports No. 106.

Kapur, S., 1975. A pedological study of three soils from s. Turkey Ph.D. Thesis. Univ of Aberdeen. 185p.

Kirsten, W.J., 1983. Organic elemental analysis: ultramicro, micro and trace methods. academic press, London.

Kiyuchevskii, V.D., 1972. Origin and evolution of the concept of soil cover pattern. Moscow. 7-14

Kurt, H. ve Arık F., 2007. Mineraloji. Nobel Yay. No: 1190. Teknik Bilimler.

Mitchell, W.A., Irmak, A., 1957. Turkish forest soils J. Soil Sci. 8:184-192.

MTA, 2008. Maden Tetkik ve Arama Gen. Müd. -Ankara

Richards, L.A., 1954. diagnosis and impovement of saline and alkali soils. USDA Agr. Handbook.No 66

Saatçı, F., 1964. İzmir Bölgesine Ait Bazı Büyük Toprak GruplarınınKil Mineralleri Üzerine Araştırmalar Ege Ün.Zir Fak.Yay. No:71, s.90. İZMIR.

Sağlam, M.T., 2008. Toprak ve Suyun Kimyasal Analiz Yöntemleri. Tekirdağ, Namık Kemal Üniversitesi Ziraat Fakültesi Yayınları. No: 2, $154 \mathrm{~S}$.

Sayın, M., 1985. Seyhan, Berdan ve Göksu Ovaları Topraklarında Toplam Mineralojik Analiz Yöntemlerinin Karşılaştırılması, Doğa Bilim Derg. 9(3): 331-341.

Sayın, M., 1999.Toprak mineralojisi.Ç.Ü.Ziraat Fak. Gen Yay. No:227. Ders kitapları yayın no:A-72, Adana.

Schlichling, E., Blume H.P., 1966, Bodenkundliches praktikum, verlang paul parey, Hamburg-Berlin

Smith, H.W., Weldon M.D., 1941. A Comparison of some methods for the determination of soil organic matter. soil science Society American Procceding. 5: 177-182.

Soil Survey Staff, 2017. Soil survey manual. United States Department of Agriculture, Handbook No.18.

Soil Survey Staff., 2014. Keys to soil taxonomy. Soil Survey Staff, U.S. Department of Agriculture, Soil Conservation Service. S.372.

Tegene, B., 1997. Varibilities of soil catena on degraded hillslopes of Watiya Catchment, Welo, Ethiopia. Sinet, an Ethiopian Journal of Science. 20(2): 151-175.

Timpson, M.E., Lee S. Y., Ammons, J.T., Foss, J.E., 1996. Mineralogical investigation of soils formed in calcareous gravelly alluvium, Eastern Crete, Greece. Soil Sci. Soc. Am. J. 60: 299-308.

USDA, 1954. US salinity laboratory diagnosis and improvement of saline and alkali soils. Agr Handbook no.60. 160p. USA.

Ülgen, N., Yurtsever N., 1995. Türkiye gübre ve gübreleme rehberi. Toprak ve Gübre Araştırma Enstitüsü Yayınları, Genel Yayın No: 209, Teknik Yayınlar No: T.66, Ankara Üzerinde Bir Araştırma. Ank. Üni. Ziraat Fak. Yay. 312. Ank. Uni. Basımevi, Ankara. 1969

Verstraten, J. M., Sevink J., 1978. Clay soils on limestone in South Limburg, The Netherlands, 2. Weathering. Geoderma. 21(4): 269-280.

Wagner, S., Costantini, E. A., Sauer, D., Stahr, K., 2007. Soil genesis in a marine terrace sequence of Sicily, Italy. Revista Mexicana de Ciencias Geológicas. 24(2): 247-260. 
ÇOMÜ Zir. Fak. Derg. (COMU J. Agric. Fac.)

2021: 9 (1): 163-177

ISSN: 2147-8384 / e-ISSN: 2564-6826

doi: $10.33202 /$ comuagri. 887265

Weitkamp, W. A., Graham R.C., Anderson M.A., Amrhein C., 1996. Pedogenesis of a vernal pool entisolalfisol-vertisol catena in Southern California. Soil Sci.Soc.Am. J. 60:316-323.

White, G.N., 2008. Scanning electron microscopy. soil science society of America, 677 S. Segoe Road,

Madison, WI 53711, USA. In: Ulery, A.L. and Drees, L.R. Ed,Method of $\quad$ Soil $\quad$ Analysis. Part 5.

Mineralogical Methods. SSSA Book Series, no.5.

Yüksel, O., Ekinci H., 2019. Determination of selected profile and productivity characteristics of soils formed on Meriç River (Turkey) Terraces. Turkish Journal of Agriculture - Food Science and Technology. 7(9): 1397-1403.

Yüksel, O., Ekinci H., 2019. Yaşlı Nehir (Meriç) terasları üzerinde yer alan bir toprak profilinin özellikleri. 1.Uluslararası Tarım ve Çevre Bilimleri Araştırmaları Kongresi. 07-08 Aralık 2019, Ankara. 